\title{
Urgensi Prinsip Kepatutan dan Keadilan (Redelijkheid en Billijkheid) Dalam Pembuatan Perjanjian Pendahuluan
}

\author{
Ragil Kusnaning Rini \\ rkusnaning@gmail.com \\ Universitas Airlangga
}

\begin{abstract}
The principle of reasonableness and fairness (redelijkheid en billijkheid) is a pair of principles that are closely related and constitute an interpretation of the principle of good faith. So that the terms used in NBW are no longer good faith, but rather reasonableness and fairness. In the Netherlands, this principle is mandatory not only at the time of contract execution, but also at the pre-contract stage, giving rise to pre-contractual liability. Whereas to judge whether or not a preliminary agreement is binding, what must be observed first is the substance and not just based on the title. The importance of applying the principles of reasonableness and fairness in the preliminary agreement is to realize contractual justice and provide protection for weak parties when the expectations of the promises offered cannot be fulfilled. In essence, the principle of reasonableness and fairness requires proportionality among the parties. A preliminary agreement if the clauses are made without paying attention to the principles of reasonableness and fairness will have the potential to cause disputes. Furthermore, the party who feels aggrieved can file a lawsuit on the basis of an unlawful act and demand compensation for the costs that have been incurred.

Keywords: Preliminary Agreements; Good Faith; Redelijkheid en Billijkheid.
\end{abstract}

$\frac{\text { Abstrak }}{\text { Prinsip kepatutan dan keadilan (redelijkheid en billijkheid) merupakan sepasang prinsip yang }}$ saling terkait erat dan merupakan penafsiran dari makna prinsip itikad baik. Sehingga istilah yang digunakan pada NBW tidak lagi itikad baik (good faith), melainkan kepatutan dan keadilan (reasonableness and fairness). Di Belanda, prinsip ini tidak hanya diwajibkan pada saat pelaksanaan kontrak saja, namun juga pada tahapan pra kontrak sehingga menimbulkan adanya pra-contractual liability. Bahwa untuk menilai mengikat atau tidaknya suatu perjanjian pendahuluan, maka yang harus dicermati terlebih dahulu adalah substansinya dan bukan hanya didasarkan pada judulnya saja. Pentingnya penerapan prinsip kepatutan dan keadilan dalam perjanjian pendahuluan adalah untuk mewujudkan keadilan berkontrak dan memberikan perlindungan terhadap pihak yang lemah manakala harapan dari janji-janji yang ditawarkan tidak dapat terpenuhi. Pada hakikatnya prinsip kepatutan dan keadilan menghendaki adanya proporsionalitas diantara para pihak. Suatu perjanjian pendahuluan jika klausul-klausulnya dibuat tanpa memperhatikan prinsip kepatutan dan keadilan akan berpotensi menimbulkan perselisihan. Selanjutnya terhadap pihak yang merasa dirugikan dapat mengajukan gugatan atas dasar perbuatan melanggar hukum dan menuntut ganti kerugian atas biaya-biaya yang telah dikeluarkannya.

Kata Kunci: Perjanjian Pendahuluan; Itikad Baik; Redelijkheid en Billijkheid. 


\section{Pendahuluan}

Hidup bermasyarakat merupakan modus survival bagi manusia yang secara kodrati sebagai makhluk bermasyarakat, artinya hanya dengan hidup bermasyarakat manusia dapat melangsungkan hidupnya. ${ }^{1}$ Seiring dengan perkembangan jaman dan diikuti dengan beragamnya perbedaan kepentingan dalam masyarakat, maka dalam rangka pertukaran kepentingan tersebut lahirlah suatu perjanjian. Perjanjian yang tertulis dan digunakan dalam dunia bisnis dan komersial tersebut lebih populer dengan sebutan kontrak. Sehingga baik perjanjian maupun kontrak mempunyai dasar pengertian yang sama yaitu adanya pertukaran antara hak dan kewajiban diantara para pihaknya. Kontrak merupakan bagian dari transaksi bisnis yang fungsinya sangat penting dalam menjamin bahwa seluruh harapan yang dibentuk dari janji-janji para pihak dapat terlaksana dan dipenuhi. ${ }^{2}$

Suatu kontrak atau perjanjian pada dasarnya berawal dari adanya perbedaan kepentingan diantara para pihak yang disertai dengan adanya penawaran dan penerimaan. Selanjutnya dalam merumuskan suatu hubungan kontraktual akan diawali dengan proses negosiasi demi mencapai kesepakatan kehendak diantara para pihak. Pada dasarnya negosiasi merupakan proses tawar-menawar di antara para pihak untuk menjajagi kemungkinan tercapainya suatu kesepakatan diantara para pihak mengenai objek dan substansi kontrak. Objek yang dimaksud meliputi title hak dan kewajiban yang akan disematkan kepada para pihak dalam kontrak. ${ }^{3}$ Negosiasi pada umumnya berada pada tahapan prakontrak dan digunakan sebagai tinjauan awal sebelum membuat perjanjian yang lebih pasti dan nantinya mengikat para pihak. Beberapa bentuk prakontrak diantaranya adalah Letter of Intent (LoI) dan Memorandum of Understanding (MoU) yang mana diintrodusir dari negara-negara yang menganut sistem common law, seperti Inggris dan Amerika

${ }^{1}$ Peter Mahmud Marzuki, Pengantar Ilmu Hukum (Prenamedia Group 2018).[41].

${ }^{2}$ Y. Sogar Simamora, Hukum Kontrak, Kontrak Pengadaan Barang dan Jasa Pemerintah di Indonesia (Laksbang Justitia 2014).[25].

${ }^{3}$ Salim H. S., Perancangan Kontrak E Memorandum of Understanding (MoU) (Sinar Grafika 2008).[9]. 
Serikat yang biasa disebut juga dengan preliminary agreement. ${ }^{4}$ Praktik peradilan di Indonesia saat ini masih menunjukkan bahwa perjanjian pendahuluan yang di dalamnya terkandung harapan dan janji tidak memiliki kekuatan mengikat secara hukum karena tidak terpenuhinya ketentuan dalam Pasal 1320 BW. Jadi meskipun perjanjian pendahuluan dapat dibuat secara lisan, namun untuk keperluan pembuktian, maka akan lebih baik jika perjanjian pendahuluan dibuat dalam bentuk tertulis. Dalam klausul perjanjian pendahuluan akan memuat janji-janji yang ditawarkan, sehingga menimbulkan harapan serta kepercayaan kepada pihak lain. Hal itulah yang kemudian melahirkan suatu kewajiban moral bagi para pihak untuk memenuhi hal-hal yang dibahas dalam perjanjian pendahuluan tersebut. Sering terjadi adanya perbuatan hukum yang mendahului suatu perjanjian pada umumnya terjadi karena adanya pengharapan dan percaya atas janji dari pihak lain dalam kegiatan negosiasi bahwa suatu kontrak atau perjanjian dapat terwujud. ${ }^{5}$ Jika akhirnya tidak tercapai kesepakatan, maka tidak dapat dituntut ganti rugi atas segala biaya yang telah dikeluarkan tersebut. Karena menurut teori kontrak klasik, belum terjadi perjanjian yang sah dan mengikat para pihak. Meskipun saat ini terjadi pergeseran dari teori klasik ke teori modern yang memandang bahwa adanya hubungan kontraktual tidak menjadi penghalang untuk diajukannya gugatan melawan hukum, karena sudah tidak lagi membedakan secara tajam antara gugatan atas dasar hubungan kontraktual dan gugatan atas dasar melawan hukum. ${ }^{6}$ Hakim dengan dasar kepatutan dapat memperluas maupun mengurangi kewajiban para pihak dalam perjanjian yang bersangkutan, dengan berpedoman pada Pasal 1339 BW dan Pasal 1347 BW. ${ }^{7}$ Melalui prinsip kepatutaan dan keadilan yang merupakan penafsiran dari prinsip iktikad baik dapat menjadi pintu masuk untuk melindungi kepentingan pihak yang

\footnotetext{
${ }^{4}$ Yohanes Sogar Simamora, 'Perjanjian Pendahuluan Dalam Pengadaan Barang/Jasa Oleh Pemerintah' (2006) 21 Yuridika.[75].

${ }^{5}$ M. Natsir Asnawi, Aspek Hukum Janji Prakontrak Telaah Dalam Kerangka Pembaruan Hukum Kontrak Di Indonesia (FH UII Press 2017).[22].

${ }^{6}$ Faizal Kurniawan, Perkembangan Hukum Perikatan Doktrin Unjustifed Enrichment Sebagai Dasar Tuntutan Ganti Rugi Untuk Mewujudkan Keadilan Berperikatan (Inteligensia Media 2017).[6].

7 Ali Imron, 'Fungsi Keseimbangan Asas Iktikad Baik Dalam Perubahan Keadaan Pada Pelaksanaan Perjanjian' (2013) 18 Jurnal Cakrawala Hukum.[8].
} 
dirugikan akibat janji yang tidak dilaksanakan tersebut. Mengingat pentingnya penerapan prinsip kepatutaan dan keadilan, maka harus dijadikan landasan dan pondasi bagi para pihak saat melakukan negosiasi dalam perjanjian pendahuluan, termasuk sejumlah janji dan komitmen yang ditawarkan dan diperjanjikan supaya dapat dimintakan pertanggungjawaban kepada pihak yang melanggar, sehingga perjanjian pendahuluan memiliki daya mengikat dan akibat yuridis.

\section{Metode Penelitian}

Tipe penelitian yang digunakan adalah Penelitian Hukum (Legal Research). Dalam penelitian ini, penulis memberikan batasan bahwa penelitian yang akan dilakukan hanya pada perjanjian pendahuluan yang sifatnya komersil. Peter Mahmud Marzuki merumuskan penelitian hukum adalah sebagai suatu proses untuk menemukan aturan hukum, prinsip-prinsip hukum, maupun doktrindoktrin hukum guna menjawab isu hukum yang dihadapi. ${ }^{8}$

Dalam penelitian ini menggunakan empat pendekatan. Pertama, pendekatan perundang-undangan (statute approach) yang dilakukan dengan cara menelaah peraturan perundang-undangan yang bersangkut paut dengan prinsip kepatutan dan keadilan terutama dengan menitikberatkan ketentuan dalam BW.

Kedua, pendekatan konseptual (conceptual approach) yang beranjak dari pandangan-pandangan atau doktrin-doktrin yang berkembang dalam ilmu hukum berkaitan dengan prinsip kepatutan dan keadilan. Pendekatan ini juga dipakai untuk memahami konsep yang berkaitan dengan penormaan prinsip kepatutan dan keadilan dalam suatu perundang-undangan dan memberikan sudut pandang dalam penelitian hukum ini.

Ketiga, pendekatan perbandingan (comparative approach) yaitu dengan membandingkankan konsep dari penerapan prinsip kepatutan dan keadilan di negara-negara lain maupun dengan peristiwa-peristiwa yang pernah terjadi dalam satu negara. Pendekatan perbandingan ini bermanfaat untuk melakukan

${ }^{8}$ Peter Mahmud Marzuki, Penelitian Hukum (Kencana Prenada Media Group 2011).[29]. 
penyikapan latar belakang dari terjadinya ketentuan hukum tertentu untuk masalah yang sama dari dua negara atau lebih yang selanjutnya dapat dijadikan rekomendasi bagi penyusunan atau perubahan dari suatu peraturan perundang-undangan. ${ }^{9}$

Keempat, pendekatan kasus (case approach) yang dilakukan dengan cara menelaah pada kasus-kasus yang berkaitan dengan isu hukum yang dihadapi. Kasus-kasus yang ditelaah merupakan kasus yang telah memperoleh putusan pengadilan berkekuatan hukum tetap. Dalam penelitian ini penulis akan melakukan penelaahan terhadap putusan pengadilan Nomor. 472 PK/Pdt/2017 tentang kekuatan mengikat pada perjanjian pendahuluan.

\section{Penerapan Prinsip Kepatutan Dan Keadilan (Redelijkheid En Billijkheid) Dalam Pembuatan Perjanjian Pendahuluan}

Prinsip hukum bukanlah merupakan hukum konkrit, namun merupakan pikiran dasar yang melatarbelakangi peraturan konkrit dalam sistem hukum yang terjelma dalam peraturan perundang-undangan dan putusan hakim yang dapat diketemukan dengan mencari ciri-ciri yang umum dalam peraturan konkrit tersebut. ${ }^{10}$ Karena sifat prinsip hukum yang abstrak maka tidak dapat diterapkan secara langsung pada peristiwa yang konkrit. Prinsip hukum merupakan sumber bagi sistem hukum yang memberi inspirasi berkaitan moral, nilai-nilai etis, dan sosial masyarakat, sehingga prinsip hukum sebagai landasan norma menjadi alat uji bagi norma hukum yang ada, pada akhirnya harus dapat dikembalikan pada prinsip hukum yang menjiwainya. ${ }^{11}$

Beberapa prinsip hukum dianggap sebagai sokoguru dari hukum perjanjian salah satunya adalah prinsip itikad baik. Meskipun penerapan prinsip itikad baik ini telah diakui dan diterima secara luas pada setiap tahapan kontrak, namun terkait batasan penafsiran makna dari prinsip itikad baik ini masih

${ }^{9}$ ibid.[172].

${ }^{10}$ Sudikno Mertokusumo, Penemuan Hukum (Sebuah Pengantar) (Liberty 2007).[5-6].

${ }^{11}$ Agus Yudha Hernoko, Hukum Perjanjian Asas Proporsionalitas Dalam Kontrak Komersial (Kencana 2010).[103]. 
diperdebatkan. Disebutkan dalam Pasal 1338 (3) BW bahwa perjanjian harus dilaksanakan dengan itikad baik. Menurut Subekti maksud dari kalimat tersebut bahwa dalam melaksanakan suatu perjanjian itu tidak boleh bertentangan dengan kepatutan dan keadilan. ${ }^{12}$ Prinsip itikad baik harus dilaksanakan pada keseluruhan tahapan kontrak.

Perkembangan doktrin itikad baik tahapan pra kontrak di negara Civil Law dipengaruhi oleh pemikiran Rudolf von Jhering dengan memperkenalkan konsep culpa in contrahendo yaitu tanggung gugat yang lahir karena kesalahan dalam negosiasi, dimana tanggung gugat selain lahir karena tidak dilaksanakannya kewajiban kontraktual tetapi juga apabila salah satu pihak lalai melakukan kewajiban beritikad baik dalam negosiasi. ${ }^{13}$ Akibat dari penerapan prinsip itikad baik tersebut, maka janji-janji yang termuat dalam perjanjian pendahuluan di negara-negara civil law memiliki daya mengikat secara hukum dan dapat dituntut pertanggungjawabannya. ${ }^{14}$

Walaupun yurisprudensi Belanda telah menerima prinsip itikad baik dalam proses negosiasi dan penyusunan kontrak, tetapi prinsip tersebut belum diadopsi pada BW Belanda (Baru), dimana pembentuk undang-undang lebih cenderung menyerahkan kepada pengadilan untuk mengembangkan dan menafsirkan prinsip tersebut. ${ }^{15}$

Penerapan prinsip kepatutan dan keadilan sebagai penafsiran dari itikad baik pada perjanjian pendahuluan di negara common law dapat dilihat dari berkembangnya doktrin promissory estoppel yaitu suatu doktrin yang melarang pihak yang telah berjanji menarik kembali janjinya tanpa alasan yang dapat dibenarkan menurut hukum dan/atau kepatutan guna memberikan perlindungan kepada pihak yang dirugikan akibat janji-janji dalam perjanjian pendahuluan yang tidak dilaksanakan oleh pemberi janji. ${ }^{16}$

\footnotetext{
${ }^{12}$ Subekti, Pokok-Pokok Hukum Perdata (Intermasa 2017).[139].

${ }^{13}$ Y. Sogar Simamora I, Op. Cit.[187].

${ }^{14}$ Suharnoko, Hukum Perjanjian: Teori Dan Analisa Kasus (Kencana Pranadamedia 2008).[3].

${ }^{15}$ Ridwan Khairandy, Itikad Baik Dalam Kontrak Di Berbagai Sistem Hukum (FH UII Press 2017).[15].

${ }^{16}$ M. Natsir Asnawi, Op.Cit.[74].
} 
Pemikiran tentang prinsip kepatutan dan keadilan ini perlu untuk dikemukakan disamping prinsip itikad baik yang sudah lama dikenal, karena pengertian prinsip itikad baik lebih abstrak pemahamannya dibandingkan dengan prinsip kepatutan dan keadilan. Sehingga untuk mencari makna dari prinsip itikad baik dalam suatu kontrak harus beranjak dari makna filosofis kepatutan dan keadilan.

Prinsip kepatutan dan keadilan (redelijkheid en billijkheid) dapat memainkan peran khusus dalam hukum kontrak, karena sepasang prinsip ini dapat mempengaruhi perjanjian kontraktual yang dibuat. Dengan kata lain, perjanjian kontrak dapat diubah dengan redelijkheid en billijkheid

Dalam NBW terkait keberadaan prinsip kepatutan dan keadilan (redelijkheid en billijkheid) dapat dijumpai pada ketentuan Artikel 6:248 NBW yang menunjukkan penggunakan reasonableness and fairness, yaitu:

(1) Een overeenkomst heeft niet alleen de door partijen overeengekomen rechtsgevolgen, maar ook die welke, naar de aard van de overeenkomst, uit de wet, de gewoonte of de eisen van redelijkheid en billijkheid voortvloeien.

(2) Een tussen partijen als gevolg van deovereenkomst geldende regel is niet van toepassing, voor zover dit in de gegeven omstandigheden naar maatstaven van redelijkheid en billijkheid onaanvaardbaar zou zijn.

Dari ketentuan dalam Artikel 6:248 (1) NBW tersebut mengisyaratkan adanya ketentuan tambahan bahwa perjanjian selain berdasarkan pada kesepakatan juga harus berlandaskan pada kepatutan dan keadilan (reasonableness and fairness). Sedangkan dari ketentuan dalam Artikel 6:248 (2) NBW adalah bahwa perjanjian harus dibatasi dengan standar kepatutan dan keadilan.

Redelijkheidadalah reasonable atau sesuai dengan akal sehat. Billijkheid adalahfairness atau patut dan adil. Makna yang pertama berhubungan dengan penalaran, sedangkan makna yang kedua berkaitan dengan perasaan. Rumusan redelijkheid en billijkheid meliputi semua hal yang ditangkap dengan akal pikiran (intelek) dan perasaan. ${ }^{17}$

\footnotetext{
${ }^{17}$ AgusYudha Hernoko, Op.Cit.[135].
} 
Pengaturan substansi itikad baik dalam NBW sebagai prinsip kepatutan dan keadilan tercantum pada ketentuan Pasal 6:2 dan 6:248 (1) NBW yangmana telah menghapus dualisme penggunaan istilah goede trouw. Pengertian itikad baik sebagaimana dimaksud dalam Pasal 1338 (3) BW diartikan dengan "redelijkheid en billijkheid", sedangkan untuk istilah goede trouw sebagaimana yang dimaksud Pasal 1963 BW dan 1977 BW tetap menggunakan istilah goede trouw. ${ }^{18}$ Untuk mencegah kemungkinan timbulnya kebingungan, maka NBW mengkarakteristikkan itikad baik sebagai reasonableness (redelijkheid) dan equity (billijkheid). ${ }^{19} \quad$ Sehingga istilah yang digunaka tidak lagi itikad baik (good faith), melainkan kepatutan dan keadilan (reasonableness and fairness). ${ }^{20}$ Doktrin ini bermakna bahwa tingkah laku para pihak dalam melaksanakan perjanjian harus diuji atas dasar norma-norma objektif yang tidak tertulis. Pasal 1374 ayat (3) BW (lama) di atas menunjuk kepada norma-norma hukum tidak tertulis, karena petunjuk itu, ia menjadi norma-norma hukum tidak tertulis. Norma-norma tersebut tidak hanya mengacu kepada anggapan para pihak saja, tetapi harus mengacu kepada tingkah laku yang sesuai dengan pandangan umum tentang iktikad baik tersebut. ${ }^{21}$ Ketentuan tersebut menentukan bahwa para pihak dalam perikatan mengikatkan dirinya atau dengan lainnya sebagai debitur dan kreditur sesuai dengan redelijkheid en billijkheid. Sehingga para pihak dalam kontrak tidak hanya terikat pada apa yang mereka sepakati saja, tetapi juga kepada redelijkheid en billijkheid.

Penerapan prinsip ini adalah untuk memberikan perlindungan dan keadilan terhadap pihak yang lemah dalam suatu perjanjian pendahuluan manakala seluruh harapan yang dibentuk dari janji-janji yang ditawarkan pada perjanjian pendahuluan tidak dapat terlaksana, dan dalam hal terdapat unsur kerugian maka akan timbul kompensasi yang harus dibayar. Pada negara-negara maju seperti Belanda, penerapan prinsip kepatutan dan keadilan atau reasonableness and fairness tidak hanya diwajibkan pada saat pelaksanaan kontrak saja, namun juga

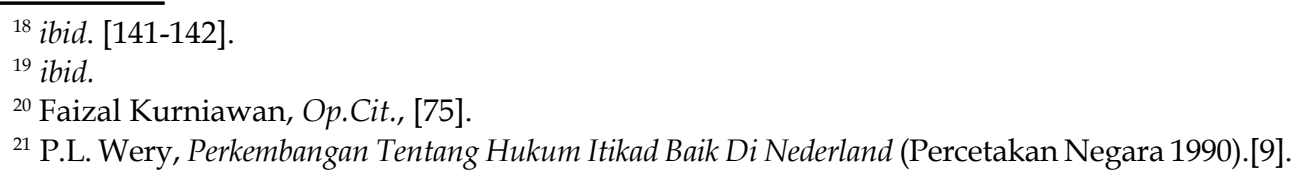


pada tahapan pra-contractual. Hal tersebut menimbulkan adanya pra-contractual liability, dimana hal tersebut tidak dikenal di Indonesia. ${ }^{22}$

Penerapan prinsip kepatutan dan keadilan dalam perjanjian pendahuluan dapat berupa adanya kewajiban untuk menjelaskan informasi tentang fakta material bagi para pihak berkaitan dengan perihal yang akan dinegosiasikan dalam perjanjian pendahuluan. Para pihak dapat melakukan pertukaran hak dan kewajiban dengan bertindak secara patut dan adil, sehingga apa yang diterima masingmasing pihak seimbang dengan apa yang telah dikeluarkannya. Selain itu prinsip kepatutan dan keadilan dapat diterapkan pada perumusan klausul-klausul dalam perjanjian pendahuluan, dimana klausul yang dicantumkan harus memperhatikan kepentingan hukum para pihaknya, logis, masuk akal, wajar dan patut.

Kewajban penerapan prinsip kepatutan dan keadilan atau reasonableness and fairness dalam perjanjian pendahuluan adalah sebagai sarana dalam mewujudkan contractual justice atau keadilan kontraktual yang merupakan tujuan mendasar dari hukum kontrak, yang tidak hanya diadopsi di negara civil law system tetapi juga di negara common law system. ${ }^{23}$

\section{Akibat Hukum Atas Klausula Dalam Perjanjian Pendahuluan Yang Tidak Mengandung Prinsip Kepatutan Dan Keadilan (Redelijkheid En Billijkheid)}

Meskipun tidak ada aturan spesifik yang mengatur tentang perjanjian pendahuluan didalam BW, namun demikian syarat pembuatan perjanjian sebagaimana diatur dalam Pasal 1320 BW dapat diterapkan untuk mengukur apakah telah terpenuhi empat syarat yang diwajibkan. Menurut Pasal 1320 BW telah disebutkan bahwa untuk syarat sahnya perjanjian diperlukan empat syarat yaitu: ${ }^{24}$

1. Sepakat mereka yang mengikatkan dirinya;

2. Cakap untuk membuat suatu perjanjian;

3. Mengenai suatu hal tertentu;

4. Sebab yang diperbolehkan.

\footnotetext{
${ }^{22}$ Faizal Kurniawan, Loc.Cit.

${ }^{23} \mathrm{ibid}$.

${ }^{24}$ Subekti, Hukum Perjanjian (Intermasa 2005).[17]. (Selanjutnya disebut Subekti II)
} 
Terhadap suatu perjanjian pendahuluan yang dibuat dengan telah memenuhi ketentuan Pasal 1320 jo Pasal 1337 BW yaitu tentang syarat sahnya perjanjian, dimana substansi yang termuat dalam perjanjian pendahuluan tersebut telah terpenuhi obyek dan causa serta secara detail telah mengatur hak dan kewajiban para pihaknya maka perjanjian pendahuluan tersebut tidak ubahnya seperti perjanjian yang sesungguhnya dan merupakan perjanjian yang sah dan mengikat diantara para pihaknya.

Pasal 1337 BW menyebutkan bahwa sebab yang diperbolehkan diartikan bahwa substansi dari perjanjian pendahuluan tersebut tidak bertentangan dengan peraturan perundang-undangan, ketertiban umum, dan kesusilaan. Sehingga jika dalam perjanjian pendahuluan termuat klausul yang tidak mengandung kepatutan dan keadilan maka perjanjian tersebut batal demi hukum, karena tidak terpenuhinya syarat obyektif.

Dalam NBW terkait pengaturan syarat hal tertentu dan sebab yang diperbolehkan tidak lagi diatur, namun disatukan dalam satu syarat yaitu perjanjian yang dilarang. Hal ini dapat ditemukan dalam ketentuan Pasal 3:40 NBW. Sehingga dalam pembaharuan hukum kontrak di Indonesia sekiranya perlu untuk mengedepankan nilai keadilan melalui penerapan prinsip kepatutan dan keadilan sebagai upaya untuk memulihkan hak-hak pihak yang dirugikan dalam perjanjian pendahuluan.

Pada hakikatnya prinsip kepatutan dan keadilan ini menghendaki adanya proporsionalitas diantara para pihak. Suatu perjanjian pendahuluan jika klausulnya dibuat tanpa memperhatikan prinsip kepatutan dan keadilan akan berpotensi menyebabkan suatu perselisihan. Selanjutnya pihak yang merasa dirugikan tersebut dapat mengajukan gugatan, namun gugatan yang diajukan bukanlah didasarkan atas hubungan kontraktual melainkan atas dasar perbuatan melanggar hukum

Pada perjanjian pendahuluan yang dibentuk konsisten dengan makna aslinya maka syarat objek dan causa tidak akan terpenuhi karena dalam perjanjian pendahuluan belum diatur secara detail mengenai hak dan kewajiban bagi para 
pihaknya. Tetapi jika substansi yang termuat dalam perjanjian pendahuluan itu telah mencerminkan suatu kontrak maka perjanjian pendahuluan yang dimaksud tidak ada bedanya dengan perjanjian yang sesungguhnya dan dengan demikian berlakulah prinsip Pacta Sunt Servanda..$^{25}$ Pengingkaran terhadap perjanjian melahirkan hak bagi pihak lain untuk mengajukan gugatan atas dasar wanprestasi. Sebaliknya, jika perjanjian yang dimaksud memang bermakna sebagai perjanjian pendahuluan, maka bagi pihak yang dirugikan tidak ada pilihan lain kecuali menggunakan dasar gugatan Perbuatan Melanggar Hukum (Onrechtmatige daad) sebagaimana diatur dalam Pasal 1365 BW. ${ }^{26}$ Mengabaikan klausul-kalusul yang termuat dalam perjanjian pendahuluan dan melakukan pelanggaran nilai-nilai moral dalam perjanjian pendahuluan dapat digugat dengan gugatan perbuatan melanggar hukum, karena bertentangan dengan kewajiban hukum,hak orang lain, kepatutan dan kesusilaan.

Dalam perkara Ny Lie Lian Joun v Arthur Tutuarima, No. 225 K/Sip/1971, Pengadilan Tinggi Bandung telah mencoba menafsirkan itikad baik yang dimaksud dalam Pasal 1338 ayat (3) BW yang menyatakan bahwa perjanjian harus dilaksanakan sesuai kepatutan dan keadilan (naar redelijkheid en billijkheid). ${ }^{27}$ Dalam perkembangannya, hakim dapat melakukan intervensi untuk memperluas maupun mempersempit hak dan kewajiban para pihak yang sebelumnya telah disepakati. Apabila tidak terdapat prinsip kepatutan dan keadilan, maka hakim dapat mengubah isi perjanjian tersebut, bahwa perjanjian tidak hanya ditentukan oleh rangkaian katakata yang disusun para pihak tetapi juga ditentukan kepatutan dan keadilan. ${ }^{28}$

Menurut Natsir Asnawi, pemikiran tentang daya mengikat janji prakontrak berangkat dari doktrin penerapan itikad baik dalam prakontrak sebagimana berkembang di negara-negara civil law dan doktrin promissory estoppel yang berkembang di negara-negara common law. ${ }^{29}$ Kedua doktrin tersebut

\footnotetext{
${ }^{25}$ Y. Sogar Simamora I, Op.Cit.[197].

${ }^{26}$ ibid

${ }^{27}$ Ridwan Khairandy, Op.Cit.[17].

${ }^{28}$ ibid. [18].

${ }^{29}$ M. Natsir Asnawi, Op.Cit.[91].
} 
memperlihatkan bahwa daya mengikat janji-janji pra kontrak terletak pada nilainilai moral yang melandasinya yaitu kepatutan dan keadilan. ${ }^{30}$

Terkait kekuatan mengikatnya perjanjian pendahuluan (MoU) dapat dilihat dari putusan pengadilan Nomor. 472 PK/Pdt/2017 dalam perkara antara PT. Jaya Makmur Bersama (Penggugat) dengan PT. Pengembangan Pariwisata Indonesia (Persero) Indonesia Tourisme Development Corporation (ITDC). Dimana Penggugat dan Tergugat sepakat menandatangani MoU yang mengatur hal-hal diantaranya para pihak bersepakat dan setuju untuk mempersiapkan penandatanganan Land Utilization and Land Development Agreement (LUDA) berdasarkan prinsip-prinsip dalam MoU, namun dalam proses pembahasan tidak tercapai kesepakatan mengenai jumlah kompensasi hingga batas waktu penandatanganan LUDA, yang kemudian MoU dinyatakan berakhir secara sepihak oleh Tergugat. Berdasarkan keadaan tersebut, selanjutnya Penggugat mengajukan gugatan ke Pengadilan dengan tuntutan bahwa Tergugat telah melakukan perbuatan wanprestasi dan menyatakan bahwa Nota Kesepahaman $(\mathrm{MoU})$ tersebut merupakan perjanjian yang mengikat antara para pihak.

Dalam membuat putusannya majelis hakim berpendapat bahwa MoU yang dibuat secara sah dan telah memuat hak dan kewajiban merupakan perjanjian yang mengikat bagi kedua belah pihak layaknya undang-undang. Apabila kewajiban yang telah diatur dalam klausula-klausula yang terdapat dalam perjanjian dilanggar, maka pihak yang melanggar dapat dikatagorikan telah wanprestasi. Dalam pertimbangannya majelis hakim menilai MoU dengan melihat subsantasinya dan tidak terpaku pada judul perjanjiannya. Menyatakan bahwa dalam MoU tersebut telah terjadi hubungan kontraktual yang mengatur hak dan kewajiban masingmasing pihak dan sesuai dengan ketentuan Pasal 1320 jo 1338 BW.

Selanjutnya dalam putusan Nomor. 472 PK/Pdt/2017 tersebut penulis melakukan analisa. Yang pertama adalah menguji MoU tersebut dengan mengkaitkan ketentuan dalam Pasal 1320 BW tentang syarat sahnya perjanjian. 
Berkaitan dengan suatu hal tertentu, bahwa dalam MoU tersebut dianggap tidak berisi cukup detail mengatur tentang obyek perjanjiannya. Adapun hak dan kewajiban yang tertuang dalam MoU tidak lain adalah untuk mengiringi kontrak sesungguhnya yang akan di buat nanti. MoU tersebut sifatnya masih dalam tahapan negosiasi, karena masing-masing piihak juga mengajukan draft perubahan untuk dapat dinegosiasikan kembali.

MoU tersebut masih belum dapat dianggap sebagai perjanjian yang final dan hanya merupakan perjanjian pendahuluan karena secara tegas dalam $\mathrm{MoU}$ tersebut para pihaknya sepakat untuk membuat perjanjian yang sesungguhnya yaitu LUDA. Artinya LUDA inilah yang dianggap dan disepakati oleh kedua belah pihak sebagai perjanjian sesungguhnya (penutupan kontrak).

Yang kedua adalah menilai adanya kerugian yang ditimbulkan dari pembuatan MoU tersebut. Meskipun MoU hanya merupakan perjanjian pendahuluan, namun terhadap apa yang telah dilaksanakan para pihak sesuai kesepakatan dalam MoU tidak dapat dikesampingkan begitu saja. Dalam hal Tergugat membatalkan MoU secara sepihak hingga Penggugat mengalami kerugian, maka Tergugat dapat dimintai pertanggungjawabannya. Yang dapat diajukan Penggugat adalah mengajukan gugatan perbuatan melanggar hukum, karena MoU tersebut sifatnya hanya sebagai pendahuluan yang tidak melahirkan perikatan. Membatalkan MoU secara sepihak dapat dituntut dengan perbuatan melanggar hukum sesuai dengan Pasal 1339 jo 1347 BW karena melanggar faktor heteronom yang menentukan daya mengikatnya suatu perjanjian yaitu syarat yang biasa diperjanjikan, kepatutan, kebiasaan dan undang-undang. Dan berdasarkan Pasal 1365 BW atas kerugian yang diderita, maka Penggugat dapat mengajukan tuntutan penggantian atas biaya-biaya yang telah dikeluarkan selama proses negosiasi.

Yang dapat dikualifikasikan sebagai perbuatan melanggar hukum (onrechtmatige daad) menurut Rosa Agustina, diperlukan empat syarat yaitu:

1. Bertentangan dengan kewajiban hukumnya sendiri;

2. Bertentangan dengan hak orang lain;

3. Bertentangan dengan kesusilaan;

4. Bertentangan dengan kepatutan, ketelitian dan kehati-hatian. 
Selanjutnya sebagaimana diatur pada ketentuan Pasal 1365 BW, dalam hal seseorang melakukan suatu perbuatan melanggar hukum dan membawa kerugian kepada orang lain maka mewajibkan kepada orang yang karena kesalahannya itu untuk mengganti kerugian tersebut. Tujuan dari gugatan melanggar hukum adalah memposisikan penggugat sebelum perbuatan melanggar hukum tersebut terjadi, sehingga ganti rugi yang dapat diberikan dalam hal ini adalah kerugian yang nyata-nyata diderita. Keuntungan dimasa datang tidak dapat diajukan dalam gugatan melanggar hukum karena dalam perjanjian pendahuluan dianggap tidak terjadi hubungan kontraktual.

Dalam hal pembaharuan hukum kontrak di Indonesia, sekiranya hakim dapat memberikan penilaian apakah para pihak dalam melaksanakan negosiasi $\mathrm{MoU}$ telah melaksanakannya dengan beritikad baik yang mengarah pada penerapan prinsip kepatutan dan keadilan (redelijkheid en billijkheid) atau tidak. Hakim juga perlu untuk mengedepankan nilai keadilan melalui penerapan prinsip kepatutan dan keadilan sebagai upaya untuk memulihkan hak-hak pihak yang dirugikan dalam perjanjian pendahuluan.

\section{Kesimpulan}

Penerapan prinsip kepatutan dan keadilan (redelijkheid en billijkheid) dalam perjanjian pendahuluan dapat dilakukan dengan menginformasikan tentang fakta material bagi para pihak berkaitan dengan perihal yang akan dinegosiasikan. Selain itu dapat diterapkan pada perumusan klausul-klausulnya yang harus memperhatikan kepentingan hukum para pihaknya, logis, masuk akal, wajar dan patut. Tujuannya untuk mewujudkan keadilan berkontrak dalam rangka memberikan perlindungan dan keadilan terhadap pihak yang lemah manakala harapan yang dibentuk dari janji-janji yang ditawarkan tidak dapat terlaksana.

Dalam perjanjian pendahuluan jika klausulnya tidak mencerminkan prinsip kepatutan dan keadilan akan berpotensi mengakibatkan perselisihan, karena dianggap telah terjadi pelanggaran nilai-nilai moral yang bertentangan dengan kewajiban hukum, hak orang lain, kepatutan dan kesusilaan. Sehingga bagi pihak 
yang dirugikan dapat mengajukan gugatan perbuatan melawan hukum termasuk atas biaya-biaya yang telah dikeluarkannya dapat dimintakan ganti kerugian.

\section{Daftar Bacaan}

\section{Buku}

Faizal Kurniawan, Perkembangan Hukum Perikatan Doktrin Unjustifed Enrichment Sebagai Dasar Tuntutan Ganti Rugi Untuk Mewujudkan Keadilan Berperikatan (Inteligensia Media 2017).

Hernoko AY, Hukum Perjanjian Asas Proporsionalitas Dalam Kontrak Komersial (Kencana 2010).

M. Natsir Asnawi, Aspek Hukum Janji Prakontrak Telaah Dalam Kerangka Pembaruan Hukum Kontrak Di Indonesia (FH UII Press 2017).

Marzuki PM, Penelitian Hukum (Kencana Prenada Media Group 2011).

- - , Pengantar Ilmu Hukum (Prenamedia Group 2018).

P.L. Wery, Perkembangan Tentang Hukum Itikad Baik Di Nederland (Percetakan Negara 1990).

Ridwan Khairandy, Itikad Baik Dalam Kontrak Di Berbagai Sistem Hukum (FH UII Press 2017).

Salim H. S., Perancangan Kontrak \& Memorandum of Understanding (MoU) (Sinar Grafika 2008).

Subekti, Hukum Perjanjian (Intermasa 2005).

- - , Pokok-Pokok Hukum Perdata (Intermasa 2017).

Suharnoko, Hukum Perjanjian: Teori Dan Analisa Kasus (Kencana Pranadamedia 2008).

Y. Sogar Simamora, Hukum Kontrak, Kontrak Pengadaan Barang Dan Jasa Pemerintah Di Indonesia (Laksbang Justitia 2014).

\section{Jurnal}

Ali Imron, 'Fungsi Keseimbangan Asas Iktikad Baik Dalam Perubahan Keadaan Pada Pelaksanaan Perjanjian' (2013) 18 Jurnal Cakrawala Hukum. 
440 | Ragil Kusnaning: Urgensi Prinsip Kepatutan...

Yohanes Sogar Simamora, 'Perjanjian Pendahuluan Dalam Pengadaan Barang/ Jasa Oleh Pemerintah' (2006) 21 Yuridika.

\section{Perundang-undangan}

Burgerlijk Wetboek (BW), Staatsblad Tahun 1847 Nomor 23.

Nieuw Nederlands Burgerlijk Wetboek (NBW).

How to cite: Ragil Kusnaning Rini, 'Urgensi Prinsip Kepatutan dan Keadilan (Redelijkheid en Billijkheid) Dalam Pembuatan Perjanjian Pendahuluan' (2021) Vol. 4 No. 3 Notaire. 